\title{
Synthesis of $C_{2}$-Symmetric Benzimidazolium Salts and Their Application in Palladium-Catalyzed Enantioselective Intramolecular $\alpha$-Arylation of Amides
}

\author{
Weiping He ${ }^{1,3}$, Wei Zhao ${ }^{1}$, Bihui Zhou ${ }^{1,3}$, Haifeng Liu ${ }^{1}$, Xiangrong Li ${ }^{1}$, Linlin Li ${ }^{1}$, Jie Li ${ }^{1, *}$ \\ and Jianyou Shi ${ }^{2, *}$ \\ 1 School of Medicine, Zhejiang University City College, No. 48, Huzhou Road, Hangzhou 310015, China; \\ wphe2016@163.com (W.H.); zhaowei@zucc.edu.cn (W.Z.); 18868816170@163.com (B.Z.); \\ maplewandering@126.com (H.L.); lixr@zucc.edu.cn (X.L.); lill@zucc.edu.cn (L.L.) \\ 2 Individualized Medication Key Laboratory of Sichuan Province, Sichuan Academy of Medical Science \& \\ Sichuan Provincial People's Hospital, School of Medicine, Center for Information in Medicine, \\ University of Electronic Science and Technology of China, Chengdu 610072, China \\ 3 College of Pharmaceutical Sciences, Zhejiang University, Hangzhou 310058, China \\ * $\quad$ Correspondence: lijie@zucc.edu.cn (J.L.); shijianyoude@126.com (J.S.); Tel.:+86-571-8801-6565 (J.L.)
}

Academic Editors: Diego A. Alonso and Isidro M. Pastor

Received: 14 April 2016; Accepted: 1 June 2016; Published: 8 June 2016

\begin{abstract}
A series of $C_{2}$-symmetric chiral benzimidazolium salts, the precursor of $N$-heterocyclic carbene ligands, were designed and synthesized from 1,2-dibromobenzene. In situ prepared corresponding carbenes were tested in the asymmetric palladium-catalyzed intramolecular $\alpha$-arylation of amides, affording chiral diarylmethanols with high yields and moderate enantioselectivities.
\end{abstract}

Keywords: $N$-heterocyclic carbene; benzimidazolium; Pd-catalyzed; asymmetric intramolecular $\alpha$-arylation

\section{Introduction}

Oxindoles (=1,3-dihydro-2H-indol-2-ones) bearing a quaternary stereogenic center at the $\mathrm{C}(3)$ position represent a prominent structural motif in many natural products and biologically active compounds [1-6], and the development of synthetic methods for these compounds is of great importance in organic chemistry. Consequently, asymmetric transition metal-catalyzed reactions that provide access to enantiomerically enriched 3-alkyl-3-aryl oxindoles were established over the past decade: Overman's elegant intramolecular Heck reactions [7-9], Trost's Pd- or Mo-mediated allylic alkylations [10-12], and the Pd-catalyzed intramolecular $\alpha$-arylation of amides, which are the focus of the present study.

Pioneered by Hartwig and co-workers, the intramolecular $\alpha$-arylation of amides provides efficient and direct access to chiral 3,3-disubstituted oxindoles. Bulky chiral N-heterocyclic carbene (NHC) ligands worked best for the asymmetric transformation (up to $70 \%$ ee) [13]. This study was followed by those of the groups of Glorius and Aoyama, but only moderate ee values were obtained [14-16]. A significant improvement in this Pd-catalyzed asymmetric reaction was achieved by Kündig and co-workers [17-21]. Since then, this chemistry has been expanded further and several other chiral carbene ligands have been reported to give the desired product in excellent enantioselectivities (Scheme 1). Dorta and co-workers reported new NHC ligands with chiral N-heterocycle and naphthyl side chains and their successful application in a Pd-catalyzed asymmetric reaction. A series of 3-alkyl-3-aryl [22], 3-allyl-3-aryl [23], and 3-flouro-3-aryl [24] oxindoles were synthesized. Additionally, conformationally restricted chiral ligands developed by Glorius [25] and Murakami [26] also showed 
high asymmetric induction in this reaction. Despite the successes in this field, new efficient chiral NHC ligands for this reaction are still needed. In this paper, we would like to report our investigation on the enantioselective intramolecular $\alpha$-arylation of amide with the new chiral carbene ligands incorporating the benzimidazole skeleton (Scheme 1).

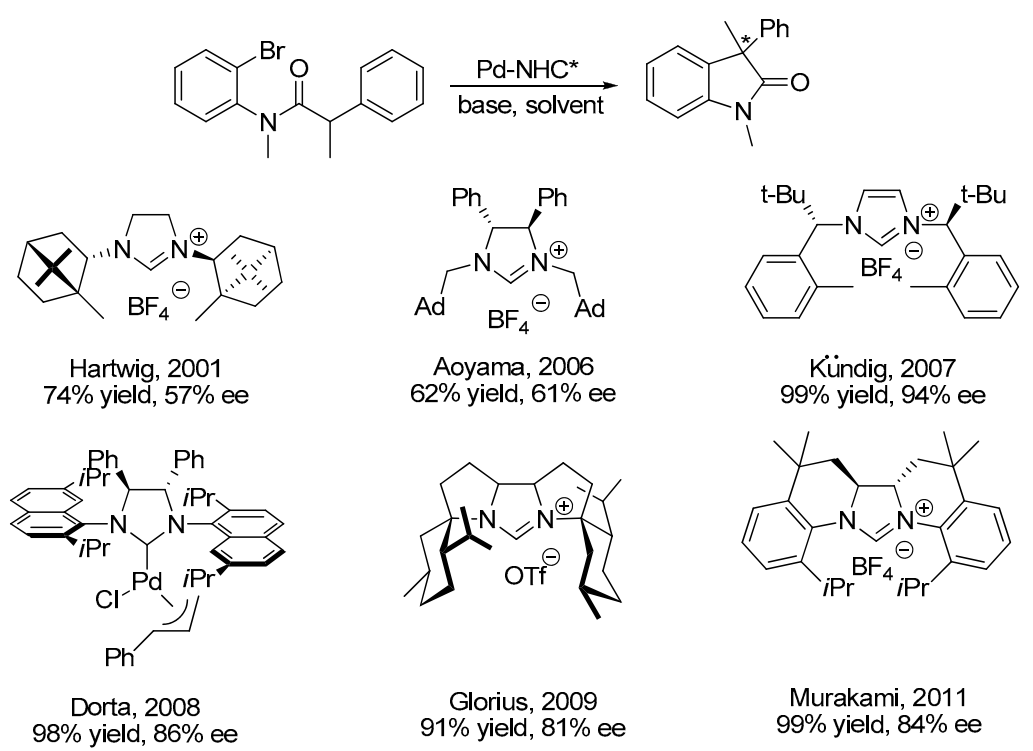

Scheme 1. Representative ligands in Pd-catalyzed asymmetric intramolecular arylation of amides.

\section{Results}

The synthesis of the benzimidazolium salt $\mathbf{3 a}$ as an $N$-heterocyclic carbene precursor is representatively shown in Scheme 2. Buchwald-Hartwig coupling of 1,2-dibromobenzene with (S)- $\alpha$-methylbenzylamine gave the disubstituted product 1a in $80 \%$ yield. Next, treatment of diamine with $\mathrm{HCl}$ in $\mathrm{CH}(\mathrm{OEt})_{3}$ gave the benzimidazolium salt $2 \mathrm{a}$ in $85 \%$ yield. The hygroscopic chloride salt 2a which became gel on exposure to the atmosphere was difficult to handle on the benchtop, but this problem was solved by anion metathesis with $\mathrm{NaI}$ to give $\mathbf{3 a}$. Other benzimidazolium salts $\mathbf{3 b}-\mathbf{d}$ were prepared in the same manner. All of the benzimidazolium salts $\mathbf{3 a - d}$ were purified and fully characterized by NMR and mass spectrometry. Furthermore, this method works equally well for milligram and multigram quantities.
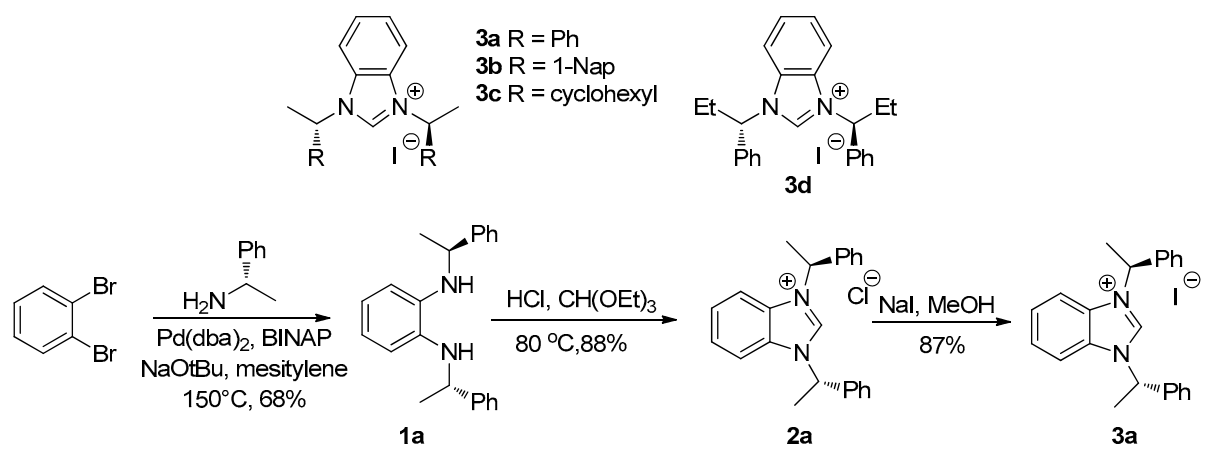

Scheme 2. Representative synthesis of benzimidazolium salt.

With the new chiral benzimidazolium salts in hand, we turned our attention to their application in the Pd-catalyzed asymmetric intramolecular arylation of amides. Ligand precursors 3a-d were tested in the intramolecular $\alpha$-arylation of $\mathbf{4 a}$ following Hartwig's in situ method (Table 1) [13]. Among 
the benzimidazolium salts screened, $3 \mathrm{c}$ possessing a cyclohexyl group as the R substituent gave better asymmetric induction ( $40 \%$ ee, entry 3$)$. With $3 \mathrm{c}$ as an $N$-heterocyclic carbene ligand precursor, the use of other solvents such as 1,4-dioxane, toluene and THF gave less satisfactory results (entries 5-7). Other bases such as $\mathrm{KO}^{t} \mathrm{Bu}, \mathrm{LiO}^{t} \mathrm{Bu}, \mathrm{KOH}$, and $\mathrm{LiOH}$ gave no better results than $\mathrm{NaO}^{t} \mathrm{Bu}$ (entries 8-11). Different palladium sources were also investigated with $3 c$, and $[\mathrm{Pd}(\text { allyl }) \mathrm{Cl}]_{2}$ emerged as the best choice of catalyst precursor (entry 14). Upon lowering the reaction temperature to rt, almost no reaction occurred; however, a $41 \%$ conversion and $48 \%$ ee were observed at $50{ }^{\circ} \mathrm{C}$ (Table 1 , entries 16,17 ).

Table 1. Chiral carbene ligands in the Pd-catalyzed intramolecular cylization of amide 4a to oxindole 5a.

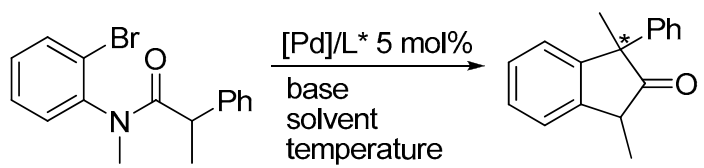

$4 a$

$5 a$

\begin{tabular}{|c|c|c|c|c|c|c|c|}
\hline Entry $^{a}$ & Ligand & {$[\mathrm{Pd}]$} & $\mathrm{T}\left({ }^{\circ} \mathrm{C}\right)$ & Solvent & Base & Yield $(\%)^{b}$ & ee $(\%)^{c}$ \\
\hline 1 & $3 a$ & $\mathrm{Pd}_{2}(\mathrm{dba})_{3}$ & 90 & DME & $\mathrm{NaO}^{t} \mathrm{Bu}$ & 51 & 14 \\
\hline 2 & $3 b$ & $\mathrm{Pd}_{2}(\mathrm{dba})_{3}$ & 90 & DME & $\mathrm{NaO}^{t} \mathrm{Bu}$ & 63 & 9 \\
\hline 3 & $3 c$ & $\mathrm{Pd}_{2}(\mathrm{dba})_{3}$ & 90 & DME & $\mathrm{NaO}^{t} \mathrm{Bu}$ & 98 & 40 \\
\hline 4 & $3 d$ & $\mathrm{Pd}_{2}(\mathrm{dba})_{3}$ & 90 & DME & $\mathrm{NaO}^{t} \mathrm{Bu}$ & 95 & 9 \\
\hline 5 & $3 c$ & $\mathrm{Pd}_{2}(\mathrm{dba})_{3}$ & 90 & dioxane & $\mathrm{NaO}^{t} \mathrm{Bu}$ & 98 & 25 \\
\hline 6 & $3 c$ & $\mathrm{Pd}_{2}(\mathrm{dba})_{3}$ & 90 & toluene & $\mathrm{NaO}^{t} \mathrm{Bu}$ & 98 & 17 \\
\hline 7 & $3 c$ & $\mathrm{Pd}_{2}(\mathrm{dba})_{3}$ & 90 & THF & $\mathrm{NaO}^{t} \mathrm{Bu}$ & 96 & 30 \\
\hline 8 & $3 c$ & $\mathrm{Pd}_{2}(\mathrm{dba})_{3}$ & 90 & DME & $\mathrm{KO}^{t} \mathrm{Bu}$ & 72 & 25 \\
\hline 9 & $3 c$ & $\mathrm{Pd}_{2}(\mathrm{dba})_{3}$ & 90 & DME & $\mathrm{LiO}^{t} \mathrm{Bu}$ & - & - \\
\hline 10 & $3 c$ & $\mathrm{Pd}_{2}(\mathrm{dba})_{3}$ & 90 & DME & $\mathrm{KOH}$ & 99 & 38 \\
\hline 11 & $3 c$ & $\mathrm{Pd}_{2}(\mathrm{dba})_{3}$ & 90 & DME & $\mathrm{LiOH}$ & - & - \\
\hline 12 & $3 c$ & $\mathrm{Pd}(\mathrm{OAc})_{2}$ & 90 & DME & $\mathrm{NaO}^{t} \mathrm{Bu}$ & 99 & 37 \\
\hline 13 & $3 c$ & $\mathrm{PdCl}_{2}$ & 90 & DME & $\mathrm{NaO}^{t} \mathrm{Bu}$ & 96 & 40 \\
\hline 14 & $3 c$ & {$[\mathrm{Pd}(\text { allyl }) \mathrm{Cl}]_{2}$} & 90 & DME & $\mathrm{NaO}^{t} \mathrm{Bu}$ & 99 & 46 \\
\hline 15 & $3 c$ & $\mathrm{Pd}\left[\mathrm{P}\left(\mathrm{C}_{6} \mathrm{H}_{5}\right)_{3}\right]_{4}$ & 90 & DME & $\mathrm{NaO}^{t} \mathrm{Bu}$ & 54 & 29 \\
\hline 16 & $3 c$ & {$[\mathrm{Pd}(\text { allyl }) \mathrm{Cl}]_{2}$} & 50 & DME & $\mathrm{NaO}^{t} \mathrm{Bu}$ & 41 & 48 \\
\hline 17 & $3 c$ & {$[\mathrm{Pd}(\text { allyl }) \mathrm{Cl}]_{2}$} & $\mathrm{rt}$ & DME & $\mathrm{NaO}^{t} \mathrm{Bu}$ & trace & - \\
\hline
\end{tabular}

a Reaction condition: [Pd] (5 mol \%), ligand (5 mol \%), base (1.5 equiv), $12 \mathrm{~h}^{\mathrm{b}}{ }^{\mathrm{b}}$ Isolated yields; ${ }^{\mathrm{c}}$ Determined by chiral HPLC (CHIRALCEL OD Column) analysis.

In the next step, different 2-bromoanilides were applied in the reaction with salt $3 \mathrm{c}$ as a catalyst precursor. As shown in Figure 1, various substrates worked well with $3 \mathrm{c}$ to give oxindoles in moderate to good yields $(28 \%-99 \%)$, and the best ee value was up to $50 \%$.

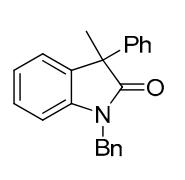

5b

$90^{\circ} \mathrm{C}, 12 \mathrm{~h}$

$66 \%, 44 \%$ ee

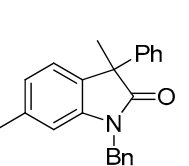

$5 \mathrm{~h}$

$90^{\circ} \mathrm{C}, 12 \mathrm{~h}$

$81 \%, 42 \%$ ee<smiles>CCC1(c2ccccc2)C(=O)N(Cc2ccccc2)c2ccccc21</smiles>

5

$$
90^{\circ} \mathrm{C}, 12 \mathrm{~h}
$$

$58 \%, 24 \%$ ee

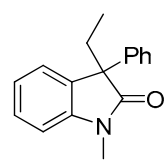

$5 d$

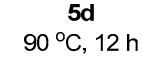

$99 \%, 27 \%$<smiles>CCCC1(c2ccccc2)C(=O)N(C)c2ccccc21</smiles>

5 e

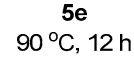

$85 \%, 28 \%$

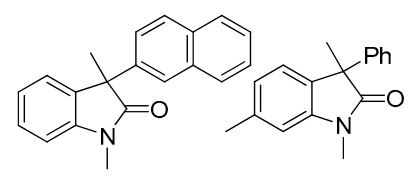

$5 f$ $90^{\circ} \mathrm{C}, 12 \mathrm{~h}$ $90^{\circ} \mathrm{C}, 12 \mathrm{~h}$ $32 \%, 36 \%$ ee

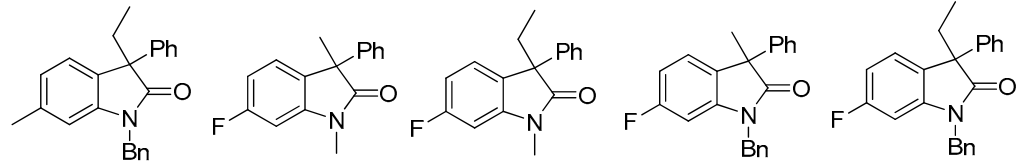

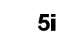

$90^{\circ} \mathrm{C}, 12 \mathrm{~h}$ $72 \%, 33 \%$ ee

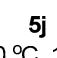

$90^{\circ} \mathrm{C}, 12 \mathrm{~h}$ $35 \%, 34 \%$ ee

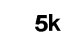

$90^{\circ} \mathrm{C}, 12 \mathrm{~h}$ $28 \%$, $26 \%$ ee
5 I $90^{\circ} \mathrm{C}, 12 \mathrm{~h}$ $68 \%, 50 \%$ ee
$5 \mathrm{~m}$

$90^{\circ} \mathrm{C}, 12 \mathrm{~h}$ $35 \%, 28 \%$ ee

Figure 1. The asymmetric reaction products. 


\section{Experimental Section}

\subsection{General}

MS spectra were measured on a Finnigan LCQDECA XP instrument and a Agilent Q-TOF 1290 LC/ $6224 \mathrm{MS}$ system; ${ }^{1} \mathrm{H}$ - and ${ }^{13} \mathrm{C}-\mathrm{NMR}$ spectra were obtained on Bruker AVANCE III $500 \mathrm{MHz}$ and $600 \mathrm{MHz}$ spectrometers (Bruker Co., Faellanden, Switzerland) with TMS as the internal standard; silica gel GF254 and H (10-40 mm, Qingdao Marine Chemical Factory, Qingdao, China) were used for TLC and CC. Unless otherwise noted, all reactions were carried out under an atmosphere of argon or nitrogen.

\subsection{Procedure for the Synthesis of Compounds 1a-d}

$\mathrm{Pd}_{2}(\mathrm{dba})_{3}(73.3 \mathrm{mg}, 0.08 \mathrm{mmol})$ and $( \pm)-\operatorname{BINAP}(99.6 \mathrm{mg}, 0.16 \mathrm{mmol})$ were dissolved in mesitylene $\left(10 \mathrm{~mL}\right.$ ) and the solution degassed for $15 \mathrm{~min}$ before being heated at $150{ }^{\circ} \mathrm{C}$ for $10 \mathrm{~min}$ (solution turns from deep purple to dark orange). Upon cooling sodium tert-butoxide (769 mg, $8.0 \mathrm{mmol}$ ), (S)- $\alpha$-methylbenzylamine (1212 mg, $10.0 \mathrm{mmol})$ and 1,2-dibromobenzene (472 mg, $2.0 \mathrm{mmol}$ ) were added and the reaction mixture was heated to $150{ }^{\circ} \mathrm{C}$ for $16 \mathrm{~h}$. The solution was allowed to cool and filtered through a pad of celite. Solvents were removed under reduced pressure and the crude material was purified by column chromatography eluting with light petroleum/ethyl acetate (50/1). Red oil (430 mg, 68\%); ${ }^{1} \mathrm{H}-\mathrm{NMR}$ spectra of $1 \mathrm{a}$ was identical to those reported in the literature [27].

Analogous compounds $\mathbf{1 b}-\mathbf{d}$ were prepared according to the similar procedure for $\mathbf{1 a}$. $\mathbf{1} \mathbf{b}: \mathbf{8 2} \%$ yield, ${ }^{1} \mathrm{H}-\mathrm{NMR}\left(500 \mathrm{MHz}, \mathrm{CDCl}_{3}\right)$ 8: 8.31-7.39 (m, 14H), $6.41(\mathrm{~m}, 4 \mathrm{H}), 5.35(\mathrm{q}, J=6.4 \mathrm{~Hz}, 2 \mathrm{H}), 1.74(\mathrm{t}$, $J=9.2 \mathrm{~Hz}, 6 \mathrm{H}) .1 \mathrm{c}: 85 \%$ yield; ${ }^{1} \mathrm{H}-\mathrm{NMR}\left(500 \mathrm{MHz}, \mathrm{CDCl}_{3}\right) \delta: 6.84-6.48(\mathrm{~m}, 4 \mathrm{H}), 3.41-3.20(\mathrm{~m}, 2 \mathrm{H})$, 1.90-0.98 (m, 28H). 1d: 84\% yield; ${ }^{1} \mathrm{H}-\mathrm{NMR}\left(500 \mathrm{MHz}, \mathrm{CDCl}_{3}\right) \delta: 7.31(\mathrm{~m}, 10 \mathrm{H}), 6.51(\mathrm{~m}, 4 \mathrm{H}), 4.25(\mathrm{t}$, $J=6.5 \mathrm{~Hz}, 2 \mathrm{H}), 2.01-1.77(\mathrm{~m}, 4 \mathrm{H}), 1.01(\mathrm{t}, J=7.4 \mathrm{~Hz}, 6 \mathrm{H})$.

\subsection{Procedure for the Synthesis of Benzimidazolium Salts 3a-d}

$1 \mathrm{a}(411 \mathrm{mg}, 1.3 \mathrm{mmol})$ was dissolved in $50 \mathrm{~mL}$ triethylorthoformate, then concentrated hydrochloric acid (37\% $w / w, 7.8 \mathrm{mmol}, 656 \mu \mathrm{L}$ of solution) was added at room temperature and the mixture was stirred for $30 \mathrm{~min}$. Then the mixture was heated to $80^{\circ} \mathrm{C}$ under air atmosphere for $12 \mathrm{~h}$. After cooling to room temperature, ether $(30 \mathrm{~mL})$ was added. The precipitate was collected by filtration. The collected solids were dissolved in $\mathrm{MeOH}(10 \mathrm{~mL})$ stirred with 5 equiv $\mathrm{NaI}$ at room temperature for $12 \mathrm{~h}$. The collected solution was concentrated and the residue was allowed to react with $\mathrm{NaI}$ again. After evaporation of volatiles, the residue was purified by column chromatography $\left(\mathrm{CH}_{2} \mathrm{Cl}_{2} / \mathrm{MeOH}=15 / 1\right)$ to give $3 a(454 \mathrm{mg}, 77 \%)$. The ${ }^{1} \mathrm{H}-\mathrm{NMR}$ and HRESIMS spectra of 3a were similar to those reported in the literature [27].

Analogous compounds $\mathbf{3 b} \mathbf{b}-\mathbf{d}$ were prepared according to the similar procedure for $\mathbf{3} \mathbf{a}$, HR-ESIMS, ${ }^{1} \mathrm{H}$ - and ${ }^{13} \mathrm{C}-\mathrm{NMR}$ data see Supplementary Materials. $3 \mathrm{~b}: 80 \%$ yield; $[\alpha]_{\mathrm{D}}^{20}=+157.8\left(c 0.2, \mathrm{CH}_{2} \mathrm{Cl}_{2}\right)$; ${ }^{1} \mathrm{H}-\mathrm{NMR}\left(500 \mathrm{MHz}, \mathrm{CDCl}_{3}\right)$ ): $11.47(\mathrm{~s}, 1 \mathrm{H}), 8.16-7.25(\mathrm{~m}, 18 \mathrm{H}), 7.08(\mathrm{q}, J=6.9 \mathrm{~Hz}, 2 \mathrm{H}), 2.51(\mathrm{~d}$, $J=6.9 \mathrm{~Hz}, 6 \mathrm{H}) ;{ }^{13} \mathrm{C}-\mathrm{NMR}\left(125 \mathrm{MHz}, \mathrm{CDCl}_{3}\right) \delta: 141.13,134.02,132.47,130.19,129.52,127.65,126.95$, 126.38, 125.48, 124.82, 121.76, 114.36, 77.29, 76.78, 56.13, 21.09; HR-ESIMS: $m / z$ 427.2294 [M - I] ${ }^{+}$(calcd for $\left.\mathrm{C}_{31} \mathrm{H}_{27} \mathrm{~N}_{2}, 427.2169\right)$. 3c: $83 \%$ yield; $[\alpha]_{\mathrm{D}}^{20}=+0.5\left(c 0.2, \mathrm{CH}_{2} \mathrm{Cl}_{2}\right) ;{ }^{1} \mathrm{H}-\mathrm{NMR}\left(500 \mathrm{MHz}, \mathrm{CDCl}_{3}\right) \delta: 11.23$ (s, 1H), $7.71(\mathrm{~m}, 4 \mathrm{H}), 4.91-4.81(\mathrm{~m}, 2 \mathrm{H}), 2.51-1.75(\mathrm{~m}, 14 \mathrm{H}), 1.47-0.77(\mathrm{~m}, 14 \mathrm{H}) ;{ }^{13} \mathrm{C}-\mathrm{NMR}(125 \mathrm{MHz}$,

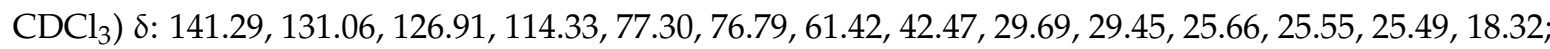
HR-ESIMS: $m / z$ 339.3016 [M - I ] ${ }^{+}$(calcd for $\left.\mathrm{C}_{23} \mathrm{H}_{35} \mathrm{~N}_{2}, 339.2795\right)$. 3d: $81 \%$ yield; $[\alpha]_{\mathrm{D}}^{20}=-19.5$ (c 0.2 , $\left.\mathrm{CH}_{2} \mathrm{Cl}_{2}\right) ;{ }^{1} \mathrm{H}-\mathrm{NMR}\left(500 \mathrm{MHz}, \mathrm{CDCl}_{3}\right) \delta: 11.82(\mathrm{~s}, 1 \mathrm{H}), 7.66-7.32(\mathrm{~m}, 14 \mathrm{H}), 6.03(\mathrm{t}, J=7.9 \mathrm{~Hz}, 2 \mathrm{H})$, 2.88-2.74 (m, 4H), $1.07(\mathrm{t}, J=7.3 \mathrm{~Hz}, 6 \mathrm{H}) ;{ }^{13} \mathrm{C}-\mathrm{NMR}\left(125 \mathrm{MHz}, \mathrm{CDCl}_{3}\right)$ 8: 136.21, 131.05, 129.45, 129.27, 127.40, 127.08, 114.41, 77.29, 76.78, 65.16, 27.11, 11.04; HR-ESIMS: $m / z 355.2381[\mathrm{M}-\mathrm{I}]^{+}$(calcd for $\left.\mathrm{C}_{25} \mathrm{H}_{27} \mathrm{~N}_{2}, 355.2169\right)$. 


\subsection{Representative Procedure for the Pd-Catalyzed Intramolecular $\alpha$-Arylation of Amides}

$\mathrm{Pd}_{2}(\mathrm{dba})_{3}(4.6 \mathrm{mg}, 0.005 \mathrm{mmol})$, chiral benzimidazolium iodide $3 \mathrm{c}$ (carbene ligand precursor) ( $4.7 \mathrm{mg}, 0.01 \mathrm{mmol}$ ) and sodium tert-butoxide $\left(29 \mathrm{mg}, 0.3 \mathrm{mmol}\right.$ ) were placed under $\mathrm{N}_{2}$ in a dry Schlenk tube. Dimethoxyethane (DME) (0.05 M in substrate, freshly distilled over $\mathrm{Na}$ ) was added and the mixture was stirred for $5 \mathrm{~min}$. The 2-bromo- $\mathrm{N}$-alkylanilide $(0.2 \mathrm{mmol})$ was then added as a solution in DME (equal volume as above). The reaction was stirred at room temperature for $12 \mathrm{~h}$. The reaction was treated with aq. $\mathrm{NH}_{4} \mathrm{Cl}(2 \mathrm{~mL})$ and extracted with ether $(3 \times 2 \mathrm{~mL})$. The combined organic phases were washed with water $(3 \mathrm{~mL})$ and brine $(3 \mathrm{~mL})$, and dried over $\mathrm{Na}_{2} \mathrm{SO}_{4}$. Flash chromatography afforded the product oxindoles. The enantiomeric purity of products $5 \mathbf{a}-\mathbf{m}$ was determined by chiral HPLC Analysis.

5a: $99 \%$ yield, $46 \%$ ee; The spectral data were comparable to those reported [17]. The ee was determined by HPLC analysis with Daicel Chiralcel OD-H (hexane $/ i-\mathrm{PrOH}=99 / 1$, flow rate $=1.0 \mathrm{~mL} / \mathrm{min}, \operatorname{tr}($ major $)=12.7 \mathrm{~min}, \operatorname{tr}($ minor $)=15.4 \mathrm{~min}) ; 5 \mathrm{~b}: 66 \%$ yield, $44 \%$ ee; The spectral data were comparable to those reported [17]. The ee was determined by HPLC analysis with Daicel Chiralcel OD-H (hexane $/ i-\mathrm{PrOH}=99 / 1$, flow rate $=1.0 \mathrm{~mL} / \mathrm{min}, \operatorname{tr}$ (major) $=14.5 \mathrm{~min}$, $\operatorname{tr}($ minor $)=16.4 \mathrm{~min}) ; 5 \mathrm{c}: 58 \%$ yield, $24 \%$ ee; The spectral data were comparable to those reported [25]. The ee was determined by HPLC analysis with Daicel Chiralcel OD-H (hexane/ $i-\mathrm{PrOH}=99 / 1$, flow rate $=1.0 \mathrm{~mL} / \mathrm{min}, \operatorname{tr}($ minor $)=13.7 \mathrm{~min}, \operatorname{tr}$ (major) $=16.2 \mathrm{~min}) ; 5 \mathrm{~d}: 99 \%$ yield, $27 \%$ ee; The spectral data were comparable to those reported [21]. The ee was determined by HPLC analysis with Daicel Chiralcel OD-H (hexane $/ i-\mathrm{PrOH}=99 / 1$, flow rate $=1.0 \mathrm{~mL} / \mathrm{min}, \operatorname{tr}$ (minor) $=11.3 \mathrm{~min}$, $\operatorname{tr}($ major $)=14.2 \mathrm{~min}) ; 5 \mathrm{e}: 85 \%$ yield $28 \%$ ee; The spectral data were comparable to those reported [15]. The ee was determined by HPLC analysis with Daicel Chiralcel OD-H (hexane $/ i-\mathrm{PrOH}=99 / 1$, flow rate $=1.0 \mathrm{~mL} / \mathrm{min}$, $\operatorname{tr}($ minor $)=12.6 \mathrm{~min}$, $\operatorname{tr}($ major $)=15.7 \mathrm{~min}) ; 5 \mathrm{f}: 82 \%$ yield, $28 \%$ ee; The ee was determined by HPLC analysis with Daciel Chiralcel OD-H (hexane $/ i-\mathrm{PrOH}=98 / 2$, flow rate $=1.0 \mathrm{~mL} / \mathrm{min}, \operatorname{tr}($ minor $)=15.4 \mathrm{~min}, \operatorname{tr}($ major $)=20.2 \mathrm{~min}) ; 5 \mathrm{~g}: 32 \%$ yield, $26 \%$ ee; The ee was determined by HPLC analysis with Daciel Chiralcel OD-H (hexane/ $i-\mathrm{PrOH}=99 / 1$, flow rate $=1.0 \mathrm{~mL} / \mathrm{min}$, $\operatorname{tr}($ major $)=10.6 \mathrm{~min}, \operatorname{tr}($ minor $)=12.2 \mathrm{~min}) ; 5 \mathrm{~h}: 81 \%$ yield, $42 \%$ ee; The ee was determined by HPLC analysis with Daciel Chiralcel OD-H (hexane $/ i-\mathrm{PrOH}=99 / 1$, flow rate $=1.0 \mathrm{~mL} / \mathrm{min}$, $\operatorname{tr}($ major $)=10.7 \mathrm{~min}, \operatorname{tr}($ minor $)=12.1 \mathrm{~min}) ; 5 \mathbf{i}: 72 \%$ yield, $33 \%$ ee; The ee was determined by HPLC analysis with Daciel Chiralcel OD-H (hexane/ $i$-PrOH $=99 / 1$, flow rate $=1.0 \mathrm{~mL} / \mathrm{min}, \operatorname{tr}($ minor $)=11.3 \mathrm{~min}, \operatorname{tr}($ major $)=12.2 \mathrm{~min}) ; 5 \mathrm{j}: 35 \%$ yield, $34 \%$ ee; The ee was determined by HPLC analysis with Daciel Chiralcel OD-H (hexane/ $i$-PrOH $=99 / 1$, flow rate $=1.0 \mathrm{~mL} / \mathrm{min}, \operatorname{tr}($ major $)=11.9 \mathrm{~min}, \operatorname{tr}($ minor $)=15.3 \mathrm{~min}) ; 5 \mathrm{k}: 28 \%$ yield, $26 \%$ ee; The ee was determined by HPLC analysis with Daciel Chiralcel OD-H (hexane/ $i-\mathrm{PrOH}=99 / 1$, flow rate $=1.0 \mathrm{~mL} / \mathrm{min}, \operatorname{tr}($ minor $)=11.3 \mathrm{~min}, \operatorname{tr}($ major $)=12.7 \mathrm{~min}) ; 51: 68 \%$ yield, $50 \%$ ee; The ee was determined by HPLC analysis with Daciel Chiralcel OD-H (hexane/i-PrOH $=99 / 1$, flow rate $=1.0 \mathrm{~mL} / \mathrm{min}, \operatorname{tr}($ major $)=11.6 \mathrm{~min}, \operatorname{tr}($ minor $)=13.6 \mathrm{~min}) ; 5 \mathrm{~m}: 35 \%$ yield, $28 \%$ ee; The ee was determined by HPLC analysis with Daciel Chiralcel OD-H (hexane $/ i-\mathrm{PrOH}=99 / 1$, flow rate $=1.0 \mathrm{~mL} / \mathrm{min}, \operatorname{tr}($ minor $)=11.9 \mathrm{~min}, \operatorname{tr}($ major $)=13.2 \mathrm{~min})$.

\section{Conclusions}

In conclusion, four chiral $C_{2}$-symmetric benzimidazolium salts $3 \mathbf{a}-\mathbf{d}$ have been prepared. Their applicability in the Pd-catalyzed asymmetric intramolecular arylation of amides has been demonstrated, and the corresponding oxindoles were obtained with high yields and moderate enantiomeric excesses (up to $50 \%$ ). Further application to other catalytic asymmetric reactions is now in progress.

Supplementary Materials: Supplementary materials can be accessed at: http://www.mdpi.com/1420-3049/21/ 6/742/s1. 
Acknowledgments: We are grateful to the National Natural Science Foundation of China (81302668) and Hangzhou Science and Technology Information Institute of China (20150633B45).

Author Contributions: Jie Li and Jianyou Shi were the principle investigators of the project, designed the experiments, and wrote the manuscript. Weiping He, Bihui Zhou, and Haifeng Liu performed the entire experiments. Wei Zhao, Xiangrong Li, and Linlin Li interpreted the results and helped write the manuscript.

Conflicts of Interest: The authors declare no conflict of interest.

\section{References}

1. Jensen, B.S. BMS-204352: Apotassium channel opener developed for the treatment of stroke. CNS Drug Rev. 2006, 8, 353-360.

2. Danishefsky, S.J. Gelsemine: A thought-provoking target for total synthesis. Angew. Chem. Int. Ed. 2003, 42, 36-51.

3. Marti, C.; Carreira, E.M. Construction of spiro[pyrrolidine-3,3'-oxindoles]-recent applications to the synthesis of oxindole alkaloids. Eur. J. Org. Chem. 2003, 2003, 2209-2219. [CrossRef]

4. Galliford, C.V.; Scheidt, K.A. Pyrrolidinyl-Spirooxindole Natural products as inspirations for the development of potential therapeutic agents. Angew. Chem. Int. Ed. 2007, 46, 8748-8758.

5. Fensome, A.; Adams, W.R.; Adams, A.L.; Berrodin, T.J.; Cohen, J.; Huselton, C.; Illenberger, A.; Kern, J.C.; Hudak, V.A.; Marella, M.A.; et al. Design, synthesis, and SAR of new pyrrole-oxindole progesterone receptor modulators leading to 5-(7-fluoro-3,3-dimethyl-2-oxo-2,3-dihydro-1H-indol-5yl)-1-methyl-1H-pyrrole-2-carbonitrile (WAY-255348). J. Med. Chem. 2008, 51, 1861-1873. [PubMed]

6. Trost, B.M.; Brennan, M.K. Asymmetric syntheses of oxindole and indole spirocyclic alkaloid natural products. Synthesis 2009, 18, 3003-3025.

7. Dounay, A.B.; Hatanaka, K.; Kodanko, J.J.; Oestreich, M.; Overman, L.E.; Pfeifer, L.A.; Weiss, M.M. Stability of thin-film solid-state electroluminescent devices based on tris(2,2'-bipyridine)ruthenium(II) complexes. J. Am. Chem. Soc. 2003, 125, 6261-6283. [CrossRef] [PubMed]

8. Dounay, A.B.; Overman, L.E. The asymmetric intramolecular Heck reaction in natural product total synthesis. Chem. Rev. 2003, 103, 2945-2963. [CrossRef] [PubMed]

9. Steven, A.; Overman, L.E. Total synthesis of complex cyclotryptamine alkaloids: Stereocontrolled construction of quaternary carbon stereocenters. Angew. Chem. Ind. Ed. 2007, 46, 5488-5508. [CrossRef] [PubMed]

10. Trost, B.M.; Frederiksen, M.U. Palladium-catalyzed asymmetric allylation of prochiral nucleophiles: Synthesis of 3-allyl-3-aryl oxindoles. Angew. Chem. Ind. Ed. 2005, 44, 308-310. [CrossRef] [PubMed]

11. Trost, B.M.; Zhang, Y. Molybdenum-catalyzed asymmetric allylation of 3-alkyloxindoles: Application to the formal total synthesis of (-)-physostigmine. J. Am. Chem. Soc. 2006, 128, 4590-4591. [CrossRef] [PubMed]

12. Trost, B.M.; Zhang, Y. Mo-catalyzed regio-, diastereo-, and enantioselective allylic alkylation of 3-aryloxindoles. J. Am. Chem. Soc. 2007, 129, 14548-14549. [CrossRef] [PubMed]

13. Lee, S.; Hartwig, J.F. Improved catalysts for the palladium-catalyzed synthesis of oxindoles by amide $\alpha$-arylation. Rate acceleration, use of aryl chloride substrates, and a new carbene ligand for asymmetric transformations. J. Org. Chem. 2001, 66, 3402-3415. [CrossRef] [PubMed]

14. Glorius, F.; Altenhoff, G.; Goddard, R.; Lehmann, C. Oxazolines as chiral building blocks for imidazolium salts and $N$-heterocyclic carbene ligands. Chem. Commun. 2002, 2704-2705. [CrossRef]

15. Arao, T.; Kondo, K.; Aoyama, T. Development of an $N$-heterocyclic carbene ligand based on concept of chiral mimetic. Tetrahedron Lett. 2006, 47, 1417-1420. [CrossRef]

16. Arao, T.; Sato, K.; Kondo, K.; Aoyama, T. Function of an N-heterocyclic carbene ligand based on concept of chiral mimetic. Chem. Pharm. Bull. 2006, 54, 1576-1581. [CrossRef] [PubMed]

17. Kündig, E.P.; Seidel, T.M.; Jia, Y.X.; Bernardinelli, G. Bulky chiral carbene ligands and their application in the palladium-catalyzed asymmetric intramolecular $\alpha$-arylation of amides. Angew. Chem. Ind. Ed. 2007, 46, 8484-8487. [CrossRef] [PubMed]

18. Jia, Y.X.; Hillgren, M.; Watson, E.L.; Marsden, S.P.; Kündig, E.P. Chiral N-heterocyclic carbene ligands for asymmetric catalytic oxindole synthesis. Chem. Commun. 2008, 4040-4042. [CrossRef] [PubMed] 
19. Jia, Y.X.; Katayev, D.; Bernardinelli, G.; Seidel, T.M.; Kündig, E.P. New chiral N-heterocyclic carbene ligands in palladium-catalyzed $\alpha$-arylations of amides: Conformational locking through allylic strain as a device for stereocontrol. Chem. Eur. J. 2010, 16, 6300-6309. [CrossRef] [PubMed]

20. Katayev, D.; Kündig, E.P. Catalytic enantioselective synthesis of a 3-aryl-3-benzyloxindole (=3-aryl-3-benzyl1,3-dihydro-2H-indol-2-one) exhibiting antitumor activity. Helv. Chim. Acta 2012, 95, 2287-2295. [CrossRef]

21. Katayev, D.; Jia, Y.X.; Sharma, A.K.; Banerjee, D.; Besnard, C.; Sunoj, R.B.; Kündig, E.P. Synthesis of 3,3-disubstituted oxindoles by palladium-catalyzed asymmetric intramolecular $\alpha$-arylation of amides: Reaction development and mechanistic studies. Chem. Eur. J. 2013, 19, 11916-11927. [CrossRef] [PubMed]

22. Luan, X.J.; Mariz, R.; Robert, C.; Gatti, M.; Blumentritt, S.; Linden, A.; Dorta, R. Matching the chirality of monodentate $N$-Heterocyclic carbene ligands: A case study on well-defined palladium complexes for the asymmetric $\alpha$-arylation of amides. Org. Lett. 2008, 10, 5569-5572. [CrossRef] [PubMed]

23. Luan, X.J.; Wu, L.L.; Drinkel, E.; Mariz, R.; Gatti, M.; Dorta, R. Highly chemo- and enantioselective synthesis of 3-allyl-3-aryl oxindoles via the direct palladium-catalyzed $\alpha$-arylation of amides. Org. Lett. 2010, 12, 1912-1915. [CrossRef] [PubMed]

24. Wu, L.L.; Falivene, L.; Drinkel, E.; Grant, S.; Linden, A.; Cavallo, L.; Dorta, R. Synthesis of 3-fluoro-3-aryl oxindoles: Direct enantioselective $\alpha$-arylation of amides. Angew. Chem. Ind. Ed. 2012, 51, 2870-2873. [CrossRef] [PubMed]

25. Würtz, S.; Lohre, C.; Fröhlich, R.; Bergander, K.; Glorius, F. IBiox[(-)-menthyl]: A sterically demanding chiral NHC ligand. J. Am. Chem. Soc. 2009, 131, 8344-8345. [CrossRef] [PubMed]

26. Liu, L.T.; Ishida, N.; Ashida, S.; Murakami, M. Synthesis of chiral N-heterocyclic carbene ligands with rigid backbones and application to the palladium-catalyzed enantioselective intramolecular $\alpha$-arylation of amides. Org. Lett. 2011, 13, 1666-1669. [CrossRef] [PubMed]

27. Rivas, F.M.; Riaz, U.; Giessert, A.; Smulik, J.A.; Diver, S.T. A versatile synthesis of substituted benzimidazolium salts by an amination/ring closure sequence. Org. Lett. 2001, 3, 2673-2676. [CrossRef] [PubMed]

Sample Availability: Samples of the compounds $3 a-d$ are available from the authors.

(C) 2016 by the authors; licensee MDPI, Basel, Switzerland. This article is an open access article distributed under the terms and conditions of the Creative Commons Attribution (CC-BY) license (http://creativecommons.org/licenses/by/4.0/). 